\section{Correlates of above-average cognitive performance among older adults: the SABE study}

\author{
Fatores de desempenho cognitivo acima da média \\ em idosos: Estudo SABE
}

\author{
Factores de rendimiento cognitivo superior \\ a la media en personas de edad avanzada: \\ estudio SABE
}

\begin{abstract}
This study aimed to identify factors associated with optimal global cognitive performance among older adults in the city of Sao Paulo, Brazil. A cross-sectional study was carried out with a sample of community-dwelling older adults who participated in the SABE Study (Health, Well-Being and Ageing) in 2006. The dependent variable was cognitive performance, categorized as "normal" or "optimal". The independent variables were socio-demographic data, lifestyle and health conditions. Data analysis involved descriptive statistics, followed by multiple logistic regression (significance set at 5\%). Optimal cognitive performance was found in $28.4 \%$ of the sample, representing 730,051 older adults. Optimal performance was associated with a younger age, a report of no difficulties regarding instrumental activities of daily living, non-abusive alcohol intake, self-rated income sufficient to meet one's daily needs and contact with family and friends. Optimal cognitive performance among older adults is associated with conditions favoring participation and independence.
\end{abstract}

Cognition; Health of the Elderly; Activities of Daily Living
Henrique Salmazo da Silva 1

Yeda Aparecida de Oliveira Duarte 2

Fabiola Bof de Andrade 1,3

Ana Teresa de Abreu Ramos Cerqueira 4

Jair Lício Ferreira Santos 5

Maria Lúcia Lebrão ${ }^{1}$

\section{Resumo}

O estudo objetivou identificar os fatores associados ao melhor desempenho cognitivo global em idosos do Município de São Paulo, Brasil. O estudo foi transversal com uma amostra composta por idosos não institucionalizados que participaram do Estudo Saúde, Bem-Estar e Envelhecimento (SABE) de 2006. A variável dependente foi o declínio cognitivo categorizado em: desempenho normal e melhor. As variáveis independentes incluíram condições sociodemográficas, estilo de vida e saúde. Realizou-se análise descritiva seguida de regressão logística múltipla, considerando-se um nível de significância de 5\%. Desempenho acima da média foi observado em 28,4\% da amostra, equivalente a 730.051 idosos. Idosos mais jovens; sem dificuldades nas atividades instrumentais de vida diária; com consumo não abusivo de álcool; autopercepção da renda como suficiente para atender as necessidades diárias e com contato social com familiares e amigos apresentaram mais chances de apresentarem melhor desempenho cognitivo acima da média. Conclui-se que desempenho cognitivo está associado à condições favoráveis de participação e independência.

Cognição; Saúde do Idoso; Atividades Cotidianas 


\section{Introduction}

Cognitive health is defined as "the development and preservation of multidimensional cognitive structure that allows the older adult to maintain social connectedness, an ongoing sense of purpose, and the abilities to function independently, to permit functional recovery from illness or injury, and to cope with residual functional deficits" 1 (p. 12). The maintenance of cognitive skills is one of the criteria used for the characterization of successful ageing and is associated with longevity, a satisfactory quality of life as well as physical and social wellbeing 2 .

The evidence indicates that older adults with normal cognitive performance maintain satisfactory degrees of autonomy 2 , independence 3 and community participation 4 . Such individuals generally have higher levels of schooling and income 5 and are younger ${ }^{3}$. Regarding lifestyle, older adults with no cognitive decline consume a moderate amount of alcohol 6 , have broader social networks 7 and participate in activities involving mental, physical and social stimulation 8 .

Most of the studies have focused either on the evaluation of factors related to the differences between individuals with cognitive decline and the ones considered to be normal ${ }^{3}$ or the predictors of maintaining cognition function 4,8. However, within the individuals with no cognitive decline the ones with above-average performances may have characteristics that make them a different group of interest for studying the cognition function, as these factors may assist in the establishment of prevention strategies aimed at preserving cognitive health among older individuals.

Thus considering the lack of evidence about the factors related to high performers with regard to cognitive function, the aim of the present study was to identify factors associated with above-average cognitive performance among older adults without cognitive decline in the city of São Paulo, Brazil.

\section{Methods}

A cross-sectional study was carried out using data collected in 2006 from the SABE study (Health, Well-Being and Ageing). The sample included survivors from the baseline study carried out in the year 2000 who participated in the second wave of the study in 2006 as well as the data on older adults from the second cohort started in 2006. All participants had no cognitive impairment and had complete information on the covariates needed for analysis. The sample was made up of 923 participants representing 730,051 community-dwelling older adults in the city of
São Paulo. The SABE study is a multicenter survey launched in 2000 and carried out in seven countries in Latin America and the Caribbean. In Brazil, the sample size was calculated to represent the urban population aged 60 years and older living in the city of São Paulo. In 2006, the survey was continued in São Paulo and a new cohort was started, thereby transforming the SABE study into a multiple cohort study. Details on the sample size calculation have been published previously ${ }^{9}$. All data were collected at the participants' homes with the use of an intervieweradministered structured questionnaire addressing socioeconomic variables, general health and living conditions as well as a set of anthropometric measures.

The sample of the present study comprised 923 elderly individuals with no cognitive decline. The exclusion of individuals with cognitive decline was based on the score of the Mini Mental State Exam (MMSE) 10 using cutoff points based on level of schooling 11 .

\section{Dependent variable}

Cognitive performance was the dependent variable and categorized as "normal" or "aboveaverage". The above-average cognitive performance was determined based on scores equal to the highest tertile (no schooling: $\geq 24$ points; 1 to 3 years of schooling: $\geq 26$ points; 4 to 7 years of schooling: $\geq 29$ points). The remaining scores were considered indicative of normal cognitive performance. Distribution in tertiles was not possible for individuals with $8+$ years of schooling, as only three scores were possible for this group following the exclusion of individuals with cognitive deficit (28, 29 and 30 points) and $59.72 \%$ of the individuals had the maximum score (30 points). Thus, 30 points was considered indicative of above-average cognitive performance in this group and $\leq 29$ points was considered indicative of normal performance. Figure 1 displays the sample selection process and distribution of participants based on cognitive performance.

\section{Independent variables}

Socio-demographic variables: age (60 to 74 years or $\geq 75$ years); conjugal relationship (yes or no); self-rated sufficiency of income for basic expenses (yes or no); and current employment (yes or no); living arrangements (single person or multi-person);

Family functioning: family functioning 12 (functional or dysfunctional) - assesses adaptation, partnership, growth, affection and resolution in the assessment of family relationships; 


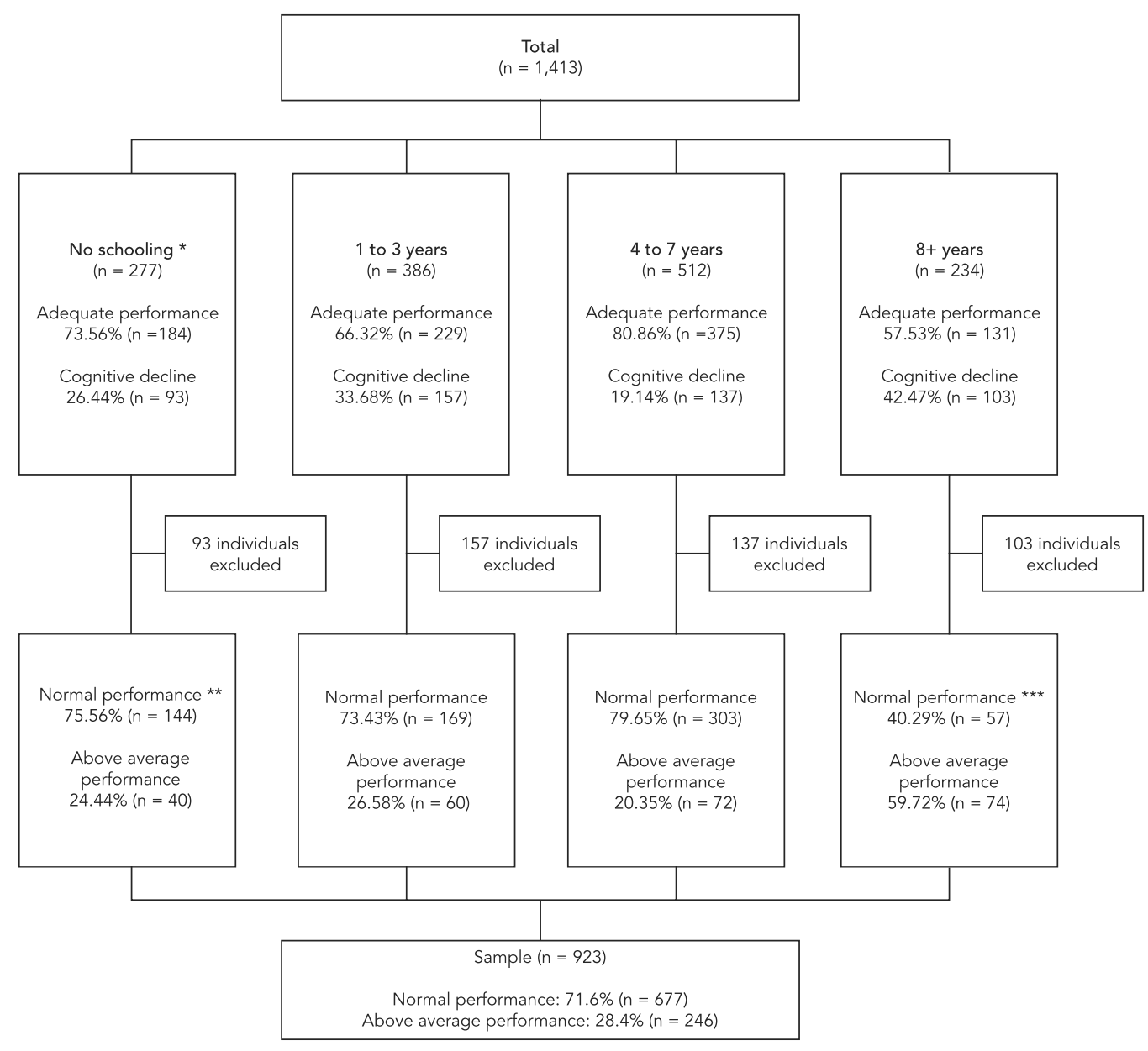

* Cut-off points for cognitive decline according to years of education: no schooling $(<19) ; 1$ to 3 years $(<23)$, 4 to 7 years $(<28), 8+$ years $(<29)$;

** Cut-off points for normal performance: no schooling ( $<24) ; 1$ to 3 years $(<26) ; 4$ to 7 years $(<29)$;

$\star * \star$ Cut-off point for normal performance $=30$.

Health conditions: depressive symptoms (yes or no: assessed by the Abbreviated Geriatric Depressive Scale) 13,14; number of self-reported chronic diseases $[0,1$ or $2+$ (arterial hypertension, diabetes mellitus, chronic obstructive pulmonary disease, heart disease, cerebrovascular disease; joint disease and osteoporosis)]; difficulty in carrying out at least one basic activity of daily living (BADL) 15 (yes or no); difficulty in carrying out at least one instrumental activity of daily living (IADL) 16 (yes or no); Questions on meal preparation and house cleaning were excluded due to the bias associated with gender 16;
Lifestyle: physical activity 17 (yes or no); alcohol consumption 18,19 (none, non-abusive alcohol intake or abusive alcohol intake); smoking 20 (non-smoker or smoker with risk); contact with family and friends [measured by the question "How often do you speak with your sons/daughters, brothers/sisters, other family members and friends?" and categorized as no contact (non-existent or sporadic contact), fair contact (weekly/ every two weeks, monthly/every six months or annually) or daily contact]; religious practices (individual practice in or out of home) [yes (once a day/several times a day/several times a week) 
or no (never/only on special occasions)]; active (frequent) participation in advanced activities of daily living [caring for or providing assistance to others, performing household chores, managing one's own business and finances, maintaining contact with others through letters, telephone calls and/or e-mail, visiting friends and family in their homes or inviting others to one's home for meals or recreational activities (yes or no)];

Past living and health conditions (first 15 years): socioeconomic status [subjective evaluation of economic status and/or self-reported food insecurity in first 15 years of life - categorized as poor socioeconomic status (poverty and/ or food insecurity) or good socioeconomic status (lack of deprivation)]; health status [self-rated health and/or having spent a month or more in bed due to a health problem in the first 15 years of life - categorized as poor health (self-rated health as poor and/or having been bedridden) or good health (self-rated health as good and/or never having been bedridden)].

\section{Data analysis}

Data analysis involved descriptive statistics for calculating frequency measures, followed by bivariate analyses. The Rao-Scott test was used to test associations between the categorical variables 21,22 . All variables with a p-value $<0.20$ in the bivariate analysis were included in the multiple regression model. The level of significance was set at $5 \%(p<0.05)$ and $95 \%$ confidence intervals were estimated. Logistic regression was used to estimate probability curves for above-average cognitive performance in function of age $(y=1)$. This study received approval from the Human Ethics Research Committee at the School of Public Health, University of São Paulo and written informed consent was obtained from the subjects before carrying out the interviews.

\section{Results}

The final sample was made up of 923 individuals, representing 730,051 community-dwelling older adults in the city of São Paulo. A total of $28.4 \%$ of the sample was classified as having above-average cognitive performance. Table 1 displays the distribution of the sample according to the independent variables. The vast majority belonged to the "60 to 74 year-old" age group and lived in multi-person home arrangements. $57.4 \%$ of the sample was made up of females. More than $70 \%$ reported being independent with regard to daily living activities.
The bivariate analysis revealed that individuals with above-average cognitive performance were younger (60 to 74 years of age), resided in multi-person home arrangements and had a conjugal partner. The prevalence of above-average cognitive performance was higher among males and individuals who reported having sufficient income to meet their daily needs. The group with above-average cognitive performance also had a lesser proportion of difficulties regarding BADLs and IADLs, maintained more contact with family and friends, managed their own finances and consumed a non-abusive amount of alcohol (Table 1).

Table 2 displays the results of the final multiple logistic regression model. Above-average cognitive performance was associated with two socio-demographic variables (age and self-rated sufficient income). Older adults with active social contact and those who consumed a non-abusive amount of alcohol had a significantly greater chance of having optimal performance and those with difficulty on IADLs had a $42 \%$ less chance of having optimal performance.

Figure 2 shows a lower likelihood of optimal performance with the increase in age. Maintaining alcohol intake and performance on IADLs constant (non-abusive alcohol intake and no difficulties on IADLs) and allowing for the progressive increase in age, individuals with social contacts and self-rated sufficient income (Model 1) had a greater likelihood of cognitive performance above-average than those with social contacts but insufficient income (Model 2) as well as those with a lack of social contact and insufficient income for basic expenses (Model 3). Maintaining all variables in the first model constant except self-rated income sufficiency, those at 60 years of age who reported insufficient income had an $8 \%$ lower likelihood of above-average cognitive performance in comparison with those with sufficient income (Model 2). The same comparison between the first model and the third model shows that those with insufficient income and a lack of social contact had about a $16 \%$ lower likelihood of above-average cognitive performance (Model 3).

\section{Discussion}

The findings of the present study indicate that people with above-average cognitive performance are different to older individuals with normal performance: they tend to be younger and independent when it comes to more complex daily living activities. Moreover they have active social contacts and report on possessing 
Table 1

Distribution of older adults with above-average cognitive performance according to independent variables.

São Paulo, Brazil, 2006.

\begin{tabular}{|c|c|c|c|}
\hline & \multirow[t]{2}{*}{ Total sample (\%) } & \multicolumn{2}{|c|}{ Cognitive performance (\%) } \\
\hline & & $\begin{array}{c}\text { Normal } \\
\text { performance }\end{array}$ & $\begin{array}{c}\text { Above-average } \\
\text { performance }\end{array}$ \\
\hline \multicolumn{4}{|l|}{ Age (years) } \\
\hline $60-74$ & 80.7 & 69.5 & 30.5 * \\
\hline $75+$ & 19.3 & 80.2 & 19.8 \\
\hline \multicolumn{4}{|l|}{ Gender } \\
\hline Male & 42.6 & 67.8 & 32.2 \\
\hline Female & 57.4 & 74.3 & $25.7 *$ \\
\hline \multicolumn{4}{|l|}{ Living condition } \\
\hline Multi-person arrangement & 86.9 & 72.9 & 27.5 \\
\hline Single person arrangement & 13.1 & 67.0 & 33.0 \\
\hline \multicolumn{4}{|l|}{ Conjugal status } \\
\hline Without partner & 39.8 & 74.3 & 25.6 \\
\hline With partner & 60.2 & 69.8 & 30.2 \\
\hline \multicolumn{4}{|l|}{ Economic status in childhood } \\
\hline Good & 25.4 & 71.5 & 28.5 \\
\hline Poor & 74.6 & 71.4 & 28.6 \\
\hline \multicolumn{4}{|l|}{ Sufficient income } \\
\hline No & 54.1 & 74.8 & $25.2^{\star *}$ \\
\hline Yes & 45.9 & 67.8 & 32.2 \\
\hline \multicolumn{4}{|l|}{ Family function } \\
\hline Functional & 90.0 & 71.7 & 28.3 \\
\hline Dysfunctional & 10.0 & 71.4 & 28.6 \\
\hline \multicolumn{4}{|l|}{ Current employment } \\
\hline No & 68.6 & 73.8 & 26.2 * \\
\hline Yes & 31.4 & 66.6 & 33.4 \\
\hline \multicolumn{4}{|l|}{ Health status in childhood } \\
\hline Good & 85.6 & 72.1 & 27.9 \\
\hline Poor & 14.4 & 66.6 & 33.4 \\
\hline \multicolumn{4}{|l|}{ Number of reported diseases } \\
\hline None & 16.1 & 76.0 & 24.0 \\
\hline 1 & 29.7 & 67.1 & 32.9 \\
\hline 2 or more & 54.2 & 71.0 & 29.0 \\
\hline \multicolumn{4}{|l|}{ Depressive symptoms } \\
\hline No & 84.0 & 71.0 & 29.0 \\
\hline Yes & 16.0 & 74.7 & 25.3 \\
\hline \multicolumn{4}{|l|}{ Difficulty on BADLs } \\
\hline None & 83.4 & 69.2 & 30.8 ** \\
\hline 1 or more & 16.6 & 82.3 & 17.7 \\
\hline \multicolumn{4}{|l|}{ Difficulty on IADLs } \\
\hline None & 73.5 & 68.1 & $31.9 * * \star$ \\
\hline 1 or more & 26.5 & 81.3 & 18.3 \\
\hline \multicolumn{4}{|l|}{ Tobacco consumption } \\
\hline Never smoked & 56.6 & 70.4 & 29.6 \\
\hline Smoker (risk) & 43.4 & 73.2 & 26.8 \\
\hline
\end{tabular}

(continues) 
Cognitive performance (\%)

$\begin{array}{cc}\begin{array}{c}\text { Normal } \\ \text { performance }\end{array} & \text { Above-average } \\ \text { performance }\end{array}$

Table 2

Final logistic regression model for above-average cognitive performance *.

\begin{tabular}{|c|c|}
\hline & $\begin{array}{c}\text { Above-average } \\
\text { cognitive performance } \\
\text { OR }(95 \% \mathrm{Cl})\end{array}$ \\
\hline 1 or more difficulties on IADLs & $0.58(0.39-0.86) * \star$ \\
\hline Non-abusive alcohol intake & $1.53(1.08-2.17) * \star$ \\
\hline Abusive alcohol intake & $1.54(0.87-2.70)$ \\
\hline Active social contacts & $1.53(1.05-2.22) * \star \star$ \\
\hline Age (continuous) & $0.96(0.94-0.99) * \star \star$ \\
\hline Self-rated income sufficiency & $1.34(1.01-1.78) * \star \star$ \\
\hline
\end{tabular}

IADLs: instrumental activities of daily living.

${ }^{*} \mathrm{n}=923$, representing 730,051 older adults; $\mathrm{p}$-value of model =0.000;

** $\mathrm{p}<0.01$;

$\star * * p<0.05$ an income that is sufficient for their basic expenses.

The differences in the methodologies used to evaluate cognitive performance and the lack of research studies evaluating individuals with a high level of cognitive performance make it difficult to compare studies. Concerning demographic and socioeconomic factors, a review of the literature reveals conflicting results regarding factors associated with cognitive performance. Some studies report that functional impairment is greater among older adults at a more advanced age 23 and among those with a lower level of schooling 8,24 . In contrast to the findings of the present study, other authors have found no association between performance and gender ${ }^{8}$. These differences between studies could be due to the methods applied to classify cognitive performance and to the analysis employed: a cross-sectional 24 and longitudinal analysis focused on the evaluation of the maintenance of cognitive function 8,23 . The increase in age in the present study led to a significant reduction in the odds of exhibiting above-average cognitive performance, which is in agreement with findings described in previous studies 2,8,25. The advance in age has been associated with a reduction in cognitive plasticity and brain 


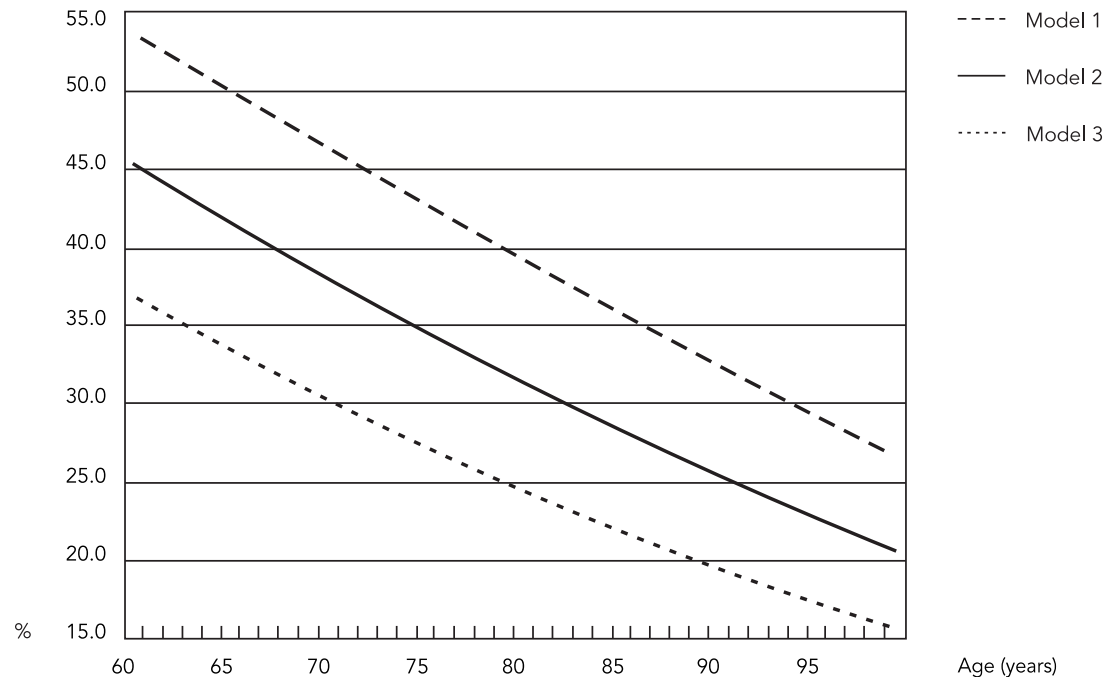

Model 1: no difficulties in instrumental activities of daily living (IADLs) + social alcohol consumption + social contacts + self-reported sufficient income; Model 2: no difficulties in IADLs + social alcohol consumption + social contacts + self-reported insufficient income; Model 3: no difficulties in IADLs + social alcohol consumption + no social contacts + self-reported insufficient income.

reserves, diminishing the efficiency of global cognitive performance 26 . Moreover, self-rated sufficient income was an important predictor of above-average cognitive performance. Studies analyzing the relationship between income and cognition report that older adults with a higher income exhibit optimal performance at baseline and lower likelihood of a reduction in performance during follow-up evaluations 27,28 . Self-rated income sufficiency may be an indication of the efficient use of cognitive resources in the planning, evaluation and management of finances, which implies a better pattern of cognitive function 29 .

The only general health variable associated with the outcome was "difficulties with instrumental activities of daily living". This association may be related to the fact that older adults with a better functional performance have greater opportunities to be cognitively active. Analyzing older American women over a 15-year period, Barnes et al. 4 found a $40 \%$ chance of maintaining a satisfactory global cognitive performance among those who reported having no difficulties on IADLs. Pérez et al. 29 found that those older adults without cognitive decline but with diffi- culties on IADLs at baseline had a greater chance of developing dementia over a ten-year followup period. Approximately half of the variance in the performance of activities of daily living is associated with cognitive performance ${ }^{30}$. Instrumental activities of daily living are those that require more sophisticated cognitive resources (memory, attention, quick reasoning, executive planning and functions, mobility, locomotion, interest, purpose and social interaction) 29 and therefore constitute a good indicator of cognitive performance among seniors 30 . However, the direction of the association may be in the opposite way considering the cross-sectional design of the study. In this case people with lower cognitive performance would have more difficulty to perform more complex activities.

In the present investigation, the number of chronic health conditions and past living and health conditions were not associated with above-average cognitive performance. This is in contrast to findings described in previous studies 4,5,31. The association between individual chronic diseases and above-average cognitive performance was also tested, but did not achieve statistical significance even in the bivariate anal- 
yses. In contrast, Barnes et al. 4 found that the maintenance of optimal performance was associated with the absence of diabetes and hypertension. Yaffe et al. 8 found a higher incidence of optimal performance among older adults without hypertension and diabetes in the bivariate analyses, but these associations lost their statistical significance after controlling for age and lifestyle. In a systematic review, some authors report that the association between chronic disease and cognition tends to be robust in studies in which the comparison group is made up of older adults with cognitive decline and dementia 5 . Once again among the reasons for the lack of association could be the design of this study, as individuals with poorer health status with regard to chronic diseases may be lost to follow-up and therefore excluded in the present wave.

Regarding lifestyle, older adults who consumed a moderate amount of alcohol had greater odds of exhibiting above-average cognitive performance. However, there is no consensus in the literature on the benefits of alcohol intake with regard to cognitive performance, the adequate amount to produce such effects 6,20 or the most beneficial type of drink 32 . According to Corley al. 6 , the ingestion of small amounts of alcohol may be related to reductions in damage to white brain matter, subclinical cerebrovascular infarction and activity associated with fibrinogen as well as increases in high-density lipoprotein cholesterol and insulin sensitivity, all of which benefit the cardiovascular system and cognitive function in old age.

Conflicting findings are reported in the literature on the effects of social networks regarding the maintenance of cognitive performance. Some longitudinal studies have found that limited social contacts were associated with an increased risk of cognitive decline 33 , whereas other investigations have found no protective effect on cognition stemming from the size of one's social network 34 , social ties and participation in groups 35 or the size, frequency and composition of social networks 36. Engagement in occupational and social activities has also been considered an indicator of above-average cognitive performance $8,24,37,38$. Older adults who remain socially active are thought to employ more cognitive resources, stimulate the potential for cerebral plasticity, benefit emotionally from interactions with others and have fewer depressive symptoms 7,39,40,41.

According to Bosma et al. ${ }^{41}$ and Salthouse 38 , the association between advanced activities of daily living and cognition may be reciprocal. The same could be observed in social relationships and in the engagement in productive ac- tivities. The non-engagement in such activities may be associated with lesser cognitive function, functional limitations, a lower income, depressive symptoms and a preclinical sign of decline in individuals classified as healthy in cognitive screening assessments 5 .

There is evidence that older adults with broader social networks are more likely to exhibit optimal global cognitive performance 7,40,42. However, the reported frequency of social contacts with family and friends was not associated with optimal performance in the present study, unlike the finding with regard to the existence of contacts. This suggests that the quality of social contacts may be more important than the quantity. Indeed, an individual can be surrounded by people, but not interact with them. This is especially true for individuals on the threshold of cognitive decline 36 .

Despite the importance of the data presented herein, the findings should be interpreted and generalized with caution, since the cross-sectional design does not make it possible to determine the direction of associations between above-average cognitive performance and the factors analyzed. Another limitation of the present study is related to the use of a screening test to evaluate cognitive performance, which does not imply that the individuals that were classified with a cognitive decline according to the cutoff points had a disease. Moreover, there are still divergences regarding the best cut-off points to be used in order to reduce the influence of education levels in the performance of the test. In this vein, individuals with low levels of education may have failed in the test in the absence of a disease and the ones with higher levels of education with mild levels of cognitive decline may have passed 43 .

The present findings confirm the notion that cognitive performance in old age is a multidetermined process and the result of different factors associated with lifestyle, living conditions and health. With the exception of the absence of chronic diseases, the present data are in agreement with the theoretical model of successful ageing proposed by Rowe \& Kahn 44, in which above-average cognitive performance is associated with the absence of disabilities and chronic diseases as well as greater engagement in life, as measured by participation in community and productive activities. The identification of factors associated with above-average cognitive performance can contribute substantially to successful ageing by allowing for the establishment of health promotion actions and prevention strategies aimed at cognitive decline. 


\section{Resumen}

Este estudio tuvo el objetivo identificar los factores asociados con el rendimiento cognitivo global óptimo entre ancianos de São Paulo, Brasil. Este fue un estudio transversal con una muestra de ancianos no institucionalizados que participaron del Estudio Salud, Bienestar y Envejecimiento (SABE) en 2006. La variable dependiente fue el rendimiento cognitivo, clasificado como "normal" o "óptimo". Las variables independientes fueron: datos sociodemográficos, estilo de vida $y$ condiciones de salud. Rendimiento cognitivo encima de la média se encontró en un $28,4 \%$, lo que representa 730.051 adultos mayores. El rendimiento encima de la média se asoció a una edad más temprana, ausencia de dificultad en las actividades instrumentales de la vida diaria, el consumo no abusivo de alcohol, el relato de ingresos suficientes para satisfacer las necesidades diarias y el contacto con amigos y familiares. El rendimiento cognitivo óptimo entre los adultos mayores se asoció con condiciones que favorecen la participación y la independencia.

Cognición; Salud del Anciano; Actividades Cotidianas

\section{References}

1. Hendrie HC, Albert MS, Butters MA, Gao S, Knopmen DS, Launer LJ, et al. The NIH Cognitive and Emotional Health Project. Report of the Critical Evaluation Study Committee. Alzheimers Dement 2006; 2:12-32.

2. Deep C, Vahia IV, Jeste D. Successful aging: focus on cognitive and emotional health. Ann Rev Clin Psychol 2010; 6:527-50.

3. Anderson TM, Sachdev PS, Bridaty H, Trollor JN, Andrews G. Effects of sociodemographic and health variables on Mini-Mental State Exam scores in older Australians. Am J Geriatr Psychiatry 2007; 15:467-76.

4. Barnes DE, Cauley JE, Lui L-Y, Fink HA, McCulloch C, Stone KL, et al. Women who maintain optimal cognitive function into old age. J Am Geriatr Soc 2007; 55:259-64.

5. Williams JW, Plassman BL, Burke J, Holsinger T, Benjamin S. Preventing Alzheimer's disease and cognitive decline. Rockville: Agency for Healthcare Research and Quality; 2010. (Evidence Reports/Technology Assessments, 193).

6. Corley J, Jia X, Brett CE, Gow AJ, Starr JM, Kyle JAM, et al. Alcohol intake and cognitive abilities in old age: the Lothian birth cohort 1936 study. Neuropsychology 2011; 25:166-75.

\section{Contributors}

H. S. Silva participated in the conception and planning of the study, the organization and analysis of data, discussions and write-up of the final version. Y. A. O. Duarte participated in the conception and project, the analysis and interpretation of data, the write-up and critical revision of the article for intellectual content, and the final approval of the version for publication. F. B. Andrade and A. T. A. R. Cerqueira contributed towards the write-up and critical revision of the article and approval of the final version for publication. J. L. F. Santos and M. L. Lebrão participated in the conception and planning, analysis and interpretation of data and approval of the final version for publication.

\section{Acknowledgments}

This study was sponsored by Fapesp (grant numbers 1999/05125-7, 2005/54947-2, 2009/06909-5).
7. Holtzman RE, Rebok GW, Sacynski JS, Kouzis AC, Doyle KW, Eaton WW. Social network characteristics and cognition in middle-aged and older adults. J Gerontol B Psychol Sci Soc Sci 2004; 59:P278-84.

8. Yaffe K, Fiocco AJ, Lindquist K, Vittinghoff E, Simonsick EM, Newman AB. Predictors of maintaining cognitive function in older adults: The Health ABC Study. Neurology 2009; 72:2029-35.

9. Andrade FB, Lebrão ML, Santos JL, Duarte YAO. Relationship between oral health and frailty in community-dwelling elderly individuals in Brazil. J Am Geriatr Soc 2013; 61:809-14.

10. Folstein MF, Folstein SE, McHugh PR. A pratical method for grading the cognitive state of patient for clinician. J Psychiatr Res 1975; 12:189-98.

11. Herreira Jr. E, Caramelli P, Silveira AS, Nitrini R. Epidemiologic survey of dementia in a communitydwelling Brazilian population. Alzheimer Dis Assoc Disord 2002; 16:103-8.

12. Duarte YAO. Família: recurso terapêutico ou fator estressor: a ótica de idosos e cuidadores familiares [Doctoral Dissertation]. São Paulo: Universidade de São Paulo; 2001.

13. Yesavage JA, Brink TL, Rose TL, Lum O, Huang V, Adey M, et al. Development and validation of a depression scale: a preliminary report. J Psychiatr Res 1983; 17:37-49. 
14. Almeida O, Almeida SA. Confiabilidade da versão brasileira da Escala de Depressäo em Geriatria (GDS) versão reduzida. Arq Neuropsiquiatr 1999; 57:421-6.

15. Katz S, Ford AB, Moskowitz RW, Jackson BA, Jaffe MW. Studies of illness in the aged. The index of ADL: a standardized measure of biological and psychosocial function. JAMA 1963; 185:914-9.

16. Lawton MP, Brody EM. Assessment of older people: self-maintaining and instrumental activities of daily living. Gerontologist 1969; 9:179-86.

17. Matsudo S, Araújo T, Marsudo V, Andrade D, Andrade E, Oliveira LC, et al. Questinário Internacional de Atividade Física (IPAQ): estudo de validade e reprodutibilidade no Brasil. Rev Bras Ativ Fís Saúde 2001; 6:5-18.

18. Blow FC, Brower KJ, Schulenberg JE, Demo-Dananberg LM, Young JP, Beresford TP. The Michigan alcoholism screening test-geriatric version (MAST-G): a new elderly-specific screening instrument. Alcohol Clin Exp Res 1992; 16:372.

19. Selzer ML. The Michigan Alcoholism Screening Test: the quest for a new diagnostic instrument. Am J Psychiatr 1971; 127:1653-8.

20. Instituto Nacional de Câncer. Inquérito domiciliar sobre comportamentos de risco e morbidade referida e doenças e agravos não transmissíveis: Brasil, 15 capitais e Distrito Federal. Rio de Janeiro: Instituto Nacional de Câncer; 2003.

21. Rao JNK, Scott AJ. On chi-squared tests for multiway contingency-tables with cell proportions estimated from survey data. Ann Stat 1984; 12:46-60.

22. Rao JNK, Scott, AJ. On simple adjustments to chisquare tests with sample survey data. Ann Stat 1987; 15:385-97.

23. Yaffe K, Lindquist K, Vittinghoff E, Barnes D, Simonsick EM, Newman A, et al. The effect of maintaining cognition on risk of disability and death. J Am Geriatr Soc 2010; 58:889-94.

24. Berkman LF, Seeman TE, Albert M, Blazer D, Kahn R, Mohs R, et al. High, usual and impaired functioning in community-dwelling older men and women: findings from the MacArthur Foundation Research Network on successful aging. J Clin Epidemiol 1993; 46:1129-40.

25. Fillenbaum GG, Hughes DC, Heyman A, George LK, Blazer DG. Relationship of health and demographic characteristics to Mini-Mental State Examination score among community residents. Psychol Med 1988; 18:719-26.

26. Lindenberger U, Baltes PB. Intellectual functioning in old and very old age: cross-sectional results from the Berlin Aging Study. Psychol Aging 1997; 12:41032.

27. Inouye S, Albert M, Mohs RC, Sun K, Berkman LF. Cognitive performance in a high-functioning community dwelling elderly population. J Gerontol 1993; 48:146-51.

28. Lee S, Kawachi I, Berkman LF, Grodstein F. Education, other socioeconomic indicators, and cognitive function. Am J Epidemiol 2003; 157:712-20.

29. Pérès K, Helmer C, Amieva H, Orgogozo JM, Rouch I, Dartigues JF, et al. Natural history of decline in instrumental activities of daily living performance over the 10 years preceding the clinical diagnosis of dementia: a prospective population-based study. J Am Geriatr Soc 2008; 56:37-44.
30. Willis SL, Schaie KW. Practical intelligence in later adulthood. In: Stenberg RJ, Wagner RK, editors. Practical intelligence: origins of competence in the everyday world. New York: Cambridge University Press; 1986. p. 236-68.

31. Turrell G, Lynch JW, Kaplan GA, Everson SA, Helkala E-L, Kauhanen J, et al. Socioeconomic position across the lifecourse and cognitive function in late middle age. J Gerontol B Psychol Sci Soc Sci 2002; 57:S43-51.

32. Solfrizzi V, D'Introno A, Colacicco AM, Capurso C, Del Parigi A, Baldassarre G, et al. Alcohol consumption, mild cognitive impairment and progression to dementia. Neurology 2007; 68:1790-9.

33. Bassuk SS, Glass K, Berkman LF. Social disengagement and incident cognitive decline in community-dwelling elderly persons. Ann Intern Med 1999; 131:165-73.

34. Glei DA, Landau DA, Goldman N, Chuang Y-L, Rodríguez G, Weinstein M. Participating in social activities helps preserve cognitive function: an analysis of a longitudinal population-based study of the elderly. Int J Epidemiol 2005; 34:864-71.

35. Seeman TE, Lusignolo TM, Albert M, Berkman L. Social relationships, social support, and patterns of cognitive studies of aging. J Health Psychol 2001; 20:243-55.

36. Green AF, Rebok G, Lyketsos CG. Influence of social network characteristics on cognition and functional status with aging. Int J Geriatr Psychiatry 2008; 23:972-8.

37. Dias EG. Atividades avançadas de vida diária no envelhecimento: um estudo de revisão [Masters Thesis]. São Paulo: Faculdade de Saúde Pública, Universidade de São Paulo; 2009.

38. Salthouse T. Mental exercise and mental aging: evaluating the validity of the "use it or lose it" hypothesis. Perspect Psychol Sci 2006; 1:68-87.

39. Hertzog C, Kramer AF, Wilson RS, Lindenberger U. Enrichment effects on adult cognitive development: can the functional capacity of older adults be preserved and enhanced? Psychol Sci Public Interest 2009; 9:1-65.

40. Barnes LL, Mendes De Leon CF, Wilson RS, Bienas JL, Evans DA. Social resources and cognitive decline in a population of older African Americans and whites. Neurology 2004; 63:2322-6.

41. Bosma H, van Boxtel MP, Ponds RW, Jelicic M, Houx P, Metsemakers J, et al. Engaged lifestyle and cognitive function in middle and old-aged, non-demented persons: a reciprocal association? Z Gerontol Geriatr 2002; 35:575-81.

42. Zuzunegui M-V, Alvarado BE, Del Ser T, Otero A. Social networks, social integration, and social engagement determine cognitive decline in communitydwelling Spanish older adults. J Gerontol B Psychol Sci Soc Sci 2003; 58:S93-100.

43. Nieuwenhuis-Mark RE. The death knoll for the MMSE: has it outlived its purpose? J Geriatr Psychiatry Neurol 2010; 23:151-7.

44. Rowe JW, Kahn R. Successful aging. New York: Pantheon Books; 1998.

Submitted on $16 /$ Jul/2013

Final version resubmitted on 30/Jan/2014

Approved on 17/Feb/2014 